\title{
Unemployment insurance and transitions in the labor mar- ket: An evaluation of the Brazilian program ${ }^{1}$
}

\author{
José Paulo Zeetano Chahad*
}

Reynaldo Fernandes**

\begin{abstract}
This paper utilizes microsimulation techniques to evaluate the impact of the Brazilian Unemployment Insurance (UI) program on individual transitions among different labor market states in order to verify whether the UI affects the duration of spells and/or their frequencies. We define four labor market states: formal employment, informal employment, unemployment, and inactivity. Our main result is that the UI impact occurs fundamentally on the inactivity of nonheads of family. The UI benefits increase both the duration and frequency of the non-head's inactivity. This happens probably because non-heads have, on average, lower wages and, therefore, a smaller importance in family income and a higher replacement rate. Our evidence does not support the hypothesis that the rise in non-head's inactivity occurs due to head's benefits.
\end{abstract}

${ }^{1}$ The authors would like to thank Fabiana de Felício for the preparation of information and support in computation and Naércio Menezes.Filho for his comments.

* Department of Economics, Universidade de São Paulo, Brazil, jpchahad@usp.br

** Department of Economics, Universidade de São Paulo, Faculdade de Economia, Administração e Contabilidade, Campus de Ribeirão Preto, Av. dos Bandeirantes, 3900, Ribeirão Preto, SP - Brazil 14040-900, Fax : +55(16)602-3910, refeman@usp.br

$\overline{\text { Brazilian Review of Econometrics Rio de Janeiro v.22, } \mathrm{n}^{\mathrm{O}} \text { 2,pp.239-274 Nov.2002 }}$ 
Unemployment insurance and transitions in the labor market

\section{Resumo}

De acordo com a literatura internacional, o seguro-desemprego origina impactos negativos sobre a oferta de trabalho em decorrência do problema da "seleção adversa" e dos efeitos do "risco moral". Como consequência são introduzidas mudanças de comportamento na escolha ocupacional realizada pelo trabalhador. Neste contexto, o valor da "taxa de reposição salarial" e a duração do "período de espera" são variáveis importantes para explicar a busca por trabalho e as transições ocupacionais observadas no mercado de trabalho. Com este arcabouço teórico em mente, o objetivo desse artigo será o de investigar algumas das principais transições no mercado de trabalho brasileiro, no período compreendido entre os anos de 1986 a 1997.

A metodologia, baseada no modelo logit multinomial, será a mesma sugerida por Clark e Summers (1990), em seu livro Understanding Unemployment. Analisaremos as transições entre quatro situações ocupacionais diferentes(empregado formal, empregado informal, desempregado e inativo). Os valores estimados do seguro-desemprego levarão em consideração três dimensões do programa: a taxa de reposição salarial, a duração do tempo do benefício e as condições de acesso. A fonte de dados será a Pesquisa Mensal de Emprego(PME-IBGE), e a unidade geográfica investigada será a Área Metropolitana de São Paulo.

Nosso resultado mais importanterevela que o impacto do seguro-desemprego ocorre, fundamentalmente, na inatividade dos não-chefes de família. $\mathrm{O}$ benefício eleva ambos, a duração e a frequência da inatividade dos não-chefes. Isto ocorre, provavelmente, porque estes indivíduos têm, na média, baixos salários e, consequentemente, uma importância menor no que diz respeito à renda familiar, e uma taxa de reposição salarial maior. As evidências obtidas não aceitam a hipótese do que a elevação da inatividade dos não-chefes ocorre em decorrência do benefício do seguro-desemprego recebido pelo chefe de família.

Key Words: unemployment insurance, unemployment, inactivity, informal sector, Brazil .

JEL Code: J65, O17. 


\section{Introduction.}

The purpose of the unemployment insurance (UI) is to improve the allocation of the unemployment risk. Unfortunately, it may also distort incentives by, for example, reducing the work effort. Moral hazard, adverse selection, and fraud problems can be more serious in the UI case than in other forms of insurance. This could be an explanation for the fact that UI has never been provided by the private sector [Chiu and Karni (1998)].

Some papers have also pointed out the beneficial effects of $\mathrm{UI}^{2}$. In the absence of private programs, the public sector could improve social welfare by providing a UI program. In this case, the policy objective would be to balance the benefit of the more efficient allocation of the unemployment risk with the cost of reduced work incentives and other distortions associated with the UI. An important research field in this direction is to empirically evaluate different UI programs in different countries. The purpose of this paper is to evaluate the impact of the Brazilian UI program on individual transitions among different labor market states in order to verify whether the UI has affected both the duration of spells and their frequency in each one of the states: formal employment, informal employment, unemployment, and inactivity.

Previous empirical research on UI has emphasized the program's effect on individual search behavior. Some of the estimates of the elasticity of spell duration with respect to UI benefit levels are large [e.g., Meyer (1990)], but Atkinson and Micklewright (1991), in a critical review of studies on unemployment compensation, argue that the findings concerning the effect of unemployment benefit levels on probability of exit from (and entry to) unemployment are far from

\footnotetext{
${ }^{2}$ See, e.g., Acemoglu and Shimer (1999a), Acemoglu and Shimer (1999b), and Marimom and Zilibotti (1999).
} 
Unemployment insurance and transitions in the labor market

robust.

An important aspect stressed by Atkinson and Micklewright is that the evidence of the benefit effects on unemployment duration in one country cannot be generalized, because the effects are strongly dependent on the institutional aspects of the program and these aspects vary considerably across countries ${ }^{3}$. Therefore, the impact of UI cannot be evaluated using only the level of benefit ${ }^{4}$. The authors also emphasize the need to distinguish different labor market states, and not to consider only employment and unemployment, as the different states may have quite different implications for the development of the economy. In general, UI can affect all transitions in the labor market and there can be more than one effect with distinct signs for each transition. This makes an a priori evaluation of the net effects of UI on transitions on the labor market very difficult ${ }^{5}$.

It is important to note that not only the level of benefits and the design of the program are important. The state of the econ-

\footnotetext{
${ }^{3}$ UI programs vary across countries (and over time) in terms of eligibility for benefits, their size and duration, and methods of financing.

${ }^{4}$ By analyzing the U.S unemployment insurance experiments, Meyer (1995) shows that different services and incentives of the programs affect the speed with which people leave the UI rolls. In the view of some authors such as Layard, Nickell and Jackman (1991), the integrated action of active and passive policies in Sweden had the effect of contributing to reduce the problems associated with moral hazard. Thus, this type of integration could be one of the explanations for the fact the Sweden has a relatively generous UI system and at the same time relatively low unemployment.

${ }^{5}$ For example, Clark and Summers (1990) present evidence that benefits to the unemployed in the United States increase the levels of both unemployment and employment. This occurs because the workers increase their level of participation in the workforce. However, the authors emphosize that part of the flows into and out of inactivity could reflect an effect caused by reporting practices and not an actual change in behaviors. In addition to inactivity, literature has suggested the inclusion of other occupational states, such os inclusion in training programs and distinctions among the various types of jobs. For an evaluation of the possible impacts of UI on transitions, see Schimid and Reissert (1995).
} 
omy can also play an important role. Thus, the same UI program applied in different countries can have different impacts in terms of the incentives generated. Here it is important to point out that the vast majority of studies of the impact of UI on transitions in the labor market have been conducted in developed countries. A distinct feature of labor markets in developing countries is the existence of a large informal sector. This makes it possible, for example, for workers that have lost their jobs in the formal sector to receive UI benefits while simultaneously holding a job in the informal sector $^{6}$. On the other hand, UI can make a job in the formal sector more attractive to many workers who, if this insurance did not exist, would opt for becoming permanently established in the informal sector. Thus, many of the effects of UI on transitions in and out of unemployment observed in studies conducted in developed countries could be reflected in flows into and out of the informal labor market in developing countries.

In our view the case of Brazil has some characteristics that make it of special interest to those engaged in evaluating UI programs. Firstly, the Brazilian program is the largest in Latin America [Thomas (1999)]. Secondly, notwithstanding the high degree of coverage of workers in the formal sector, more than half of the occupied population does not have a formal labor contract and thus does not have the right to UI benefits. Thirdly, Brazil has neither an experience rating system nor mechanisms to monitor the search for a new job. Fourthly, UI is not the only program that provides resources to the unemployed worker. These aspects tend to aggravate

\footnotetext{
${ }^{6}$ In general, only workers in the formal sector are insured. On the other hand, free entry to the informal sector has been cited as one of the most important characteristics for at least a significant part of this segment [Fields (1990)]. These aspects together with the difficulties encountered in monitoring make the strategy of receiving UI benefits while holding a job in the informal sector a relatively easy option to adopt.
} 
the moral hazard problems. Finally, the Brazilian program dates back to 1986 and it has suffered many changes since then, including changes in the rate of wage replacement (replacement rate), in the number of parcels, and, most importantly, in the eligibility criteria, which have been relaxed over time. Therefore, the benefits expected from the program vary in a fixed period of time for individuals with different characteristics; and over time for individuals with the same characteristics. This variation is extremely convenient for the type of study conducted here, in the sense of providing the identification conditions needed for a carefully crafted empirical work to be carried out.

This paper utilizes microsimulation techniques and as such is subject to all the limitations of this type of approach, especially to aggregation problems. The strategy assumes that the individual probabilities of transition among different states are independent. While this can be true for the sample used in estimation, it is unlikely to be true for the population from which the sample is drawn. Therefore, the impacts of UI on, for example, the policy for determining the level of employment and wages inside the firms were not taken into account in this exercise.

The paper is organized in four sections aside from the introduction. The next section briefly describes the Brazilian UI program. Section three presents the methodology used and the principal results are presented in section four. Finally, the last section concludes.

\section{The Brazilian UI Program.}

The program grew considerably from its implementation in 1986 until the end of 1998. By 1998, the program provided benefits to about 4.4 million workers, approximately $6 \%$ of the labor force, and the average benefit payment was equivalent to 1.56 monthly minimum wage, which represents an annual expenditure of US $\$ 3.5$ billion 
or some $0.58 \%$ of GDP.

Nowadays, the basic criterion for eligibility to the program is that the worker must have received wages for a continuous period of six months immediately prior to having been fired. Voluntary quitting is not covered. The criteria for eligibility have become more inclusive over time. At the beginning of the program, workers, in addition to the above requirement and other restrictions, were required to prove that they had contributed to the Social Security System for at least 36 months out of the last 48 months. The main changes to these criteria occurred in the early 1990s, between 1987 and 1992 the number of beneficiaries was multiplied by 5.3 .

Once a worker is considered eligible for benefits he has the right to receive a number of benefit payments for a period of time (benefit period), which is currently set at 16 months $^{7}$. The number of benefit payments varies from 3 to 5 , depending on the worker's previous period of employment ${ }^{8}$. From the beginning of the program until June 1994, the number of benefit payments was fixed at four. In theory, payments were to be suspended once the worker found a new job or began to receive another source of income. However, there is no mechanism of enforcement in place and workers are not subject to an integrated job and training program. In practice, payments are only suspended if the new job is in the formal sector. Even if employment is in the formal sector, there are many ways to avoid compliance with legislation ${ }^{9}$.

\footnotetext{
${ }^{7}$ Until January 1990 the benefit period was set at 18 months. The benefit period establishes the period of time that the worker must wait to be again eligible to receive benefits, once all other eligibility criteria have been met. Within the benefit period, the receipt of benefit payments may be continuous or internittent.

${ }^{8} \mathrm{~A}$ period of employment from six to 11 months gives the worker the right to three benefit payments; from 12 to 23 months, 4 payments; and from 24 months onwards, 5 payments.

${ }^{9}$ Workers may hold more than one employment registry booklet, which makes it difficult to
} 
From the beginning of the program until July 1987, the monthly benefit payment was equal to $50.0 \%$ of the previous wage for workers earning up to three minimum wages (MW) and 1.5 times the MW $(1.5 \mathrm{MW})$ for workers that earned more than $3 \mathrm{MW}$. The minimum amount of the monthly benefit was set at $0.7 \mathrm{MW}$. In May 1995, the monthly benefit payment was equal to $80.0 \%$ of the previous wage for workers earning up to $1.65 \mathrm{MWW}$; and $1.32 \mathrm{MW}$ plus $50.0 \%$ of the difference between the actual wage and $1.65 \mathrm{MW}$ for workers that earned between $1.65 \mathrm{MW}$ and $2.75 \mathrm{MW}$; and $1.87 \mathrm{MW}$ for workers that earned over $2.75 \mathrm{MW}$. In order to comply with the constitutional mandate, since January 1990, the minimum monthly benefit was set at the level of MW. Various changes to these rules took place between August 1987 and May 1995.

Compared to OECD countries, Brazil does not have "generous" UI benefits, although the criteria for eligibility for workers in the formal sector are relatively easy to meet. Nevertheless, the argument has been made that very strong adverse incentives are generated by the program, due to other characteristics of the program and of the Brazilian labor market ${ }^{1 \bullet}$. The most important of these characteristics are:

(i) In Brazil, in contrast to the case of countries such as the United States, the contributions of firms to the fund that grants the payment of benefits to unemployed workers is not linked to the number of dismissals that this makes. This marginally reduces the cost of dismissal and thereby increases the probability of dismissals ${ }^{11}$;

\footnotetext{
ascertain if he is actively employed.

${ }^{10}$ See, for example, Barros, Corseuil and Fogel (1999).

${ }^{11}$ Contributions by firms occur indirectly through contributions to the Workers' Support Fund (FAT). In addition to fnancing UI, FAT finances other programs that provide assistance to workers, such as a professional training program. It is important to note that although other workers'
} 
(ii) UI is only one of the programs that provide benefits to unemployed workers. Another important program is the "Workers' Tenure Fund" (FGTS). FGTS serves as a compulsory savings account that workers may access on certain occasions, particularly in the case of being fired ${ }^{12}$. In addition to low liquidity, FGTS balances are remunerated at interest rates that are significantly lower than those of the market. With the objective of gaining access to their FGTS funds, workers may act so as to increase their probability of dismissal. This behavior is further reinforced by the existence of a fine $(40.0 \%$ incident on the balance of the fund) that the firm must pay to the worker in the event of his dismissal ${ }^{13}$;

(iii) The impact of UI on the time spent looking for a job may be magnified by the large size of the informal labor market in Brazil.

Since the beginning of the UI program, some analysts warned that the design proposed was inadequate in terms of stimulating the search for a new job. With the development of new sources of information, recent studies have confirmed the fact that Brazil's UI program seems to have failed, at least in part, in its attempt to be a mechanism of financial support to facilitate the search for a new job. This is because the majority of beneficiaries were not

\footnotetext{
assistance programs exist, these programs are completely separate.

${ }^{12}$ Firms are required to make a monthly deposit in the worker's account equal to $8.0 \%$ of their monthly wage. In addition to dismissal, other important reasons for accessing the funds are retirement and the purchase of a home. In the event of death of the account holder the funds may be withdrawn by a dependent.

${ }^{13}$ As is the case with UI, workers cannot access their FGTS balance if they leave their job voluntarily. However, in many cases workers that leave their jobs voluntarily are registered as being fired. In these cases the worker returns the amount of the fine paid by the firm and then is able to withdra w the FGTS balance and receive the unemployment benefits. Barros, Corseuil and Fogel (1999) present evidence that around 2/3 of employees in the formal sector that voluntarily left their jobs had access to their FGTS balance.
} 
actively involved in the search for employment at the time of their interview. The majority of them were either employed or inactive ${ }^{14}$. It is important to point out that the fact that a person has received UI in the last 30 days (which is how the question is formulated) while at the same time being employed does not necessarily mean an infringement of the legislation. The person could have become employed after receiving the benefits.

Table 1 - Beneficiaries of unemployment insurance in the last 30 days

\begin{tabular}{|c|c|c|c|c|c|c|c|}
\hline & $\begin{array}{c}\text { Beneficiaries } \\
(\%)\end{array}$ & $\begin{array}{l}\text { Avg. } \\
\text { Work } \\
\text { Week } \\
\text { (hrs) }\end{array}$ & $\begin{array}{l}\text { Avg. } \\
\text { Income } \\
(\mathrm{R} \$)^{*}\end{array}$ & $\begin{array}{c}\text { Avg.UI } \\
(\mathrm{R} \$)\end{array}$ & $\begin{array}{l}\text { Avg. } \\
\text { UI/ } \\
\text { Average } \\
\text { Income }\end{array}$ & $\begin{array}{l}\text { With } \\
\text { Formal } \\
\text { Contract }\end{array}$ & $\begin{array}{l}\% \text { with } 0 \\
\text { Income } \\
\text { and } \\
\text { Missing }\end{array}$ \\
\hline $\begin{array}{l}\text { Unemployed } \\
\text { (month) }\end{array}$ & $26.03 \%$ & - & - & 126.58 & - & - & - \\
\hline $\begin{array}{l}\text { Inactive } \\
\text { (month) }\end{array}$ & $23.29 \%$ & - & - & 187.35 & - & - & - \\
\hline $\begin{array}{l}\text { Employed } \\
\text { (less than } 1\end{array}$ & $\begin{array}{l}12.33 \% \\
\text { nonth) }\end{array}$ & 42 & 50.00 & 141.88 & 283.75 & 55.60 & 88.89 \\
\hline $\begin{array}{l}\text { Employed } \\
\text { (from } 1 \text { to } 2\end{array}$ & $\begin{array}{l}10.96 \% \\
\text { months) }\end{array}$ & 51 & 279.38 & 172.63 & 61.79 & 0.00 & 0.00 \\
\hline $\begin{array}{l}\text { Employed } \\
\text { (more than } 2\end{array}$ & $\begin{array}{c}10.96 \% \\
\text { months) }\end{array}$ & 42 & 73.9 .88 & 238.63 & 32.25 & 50.00 & 0.00 \\
\hline$\overline{M i s s i n g}$ & $16.44 \%$ & - & - & - & - & - & - \\
\hline
\end{tabular}

* Only income other than 0 and missing are included.

Source: PPV - IBGE.

\footnotetext{
${ }^{14}$ See Barros, Corseuil and Fogel (1999) and Thomas (1999). These studies are based on figures from the Living Standards Report (Pesquisa sobre Padröes de Vida-PPV) of the IBGE. The PPV covers the South and Northeast Region, which represent approximately $65.0 \%$ of Brazil's population.
} 
Table 1 above uses the same source of information as the above studies to describe the labor market status of UI beneficiaries. The tables show that $36.0 \%$ of those employed stated that they were in the job for less than one month ${ }^{15}$. Although the size of the sample was small, the table provides evidence that a significant part of beneficiaries received UI benefits along with the wage of a current job. Another part received UI while they were not actively looking for a new job. The table also shows that for beneficiaries employed for more than one month, both the workweek and the level of income indicate that these jobs are not of short-term nature. Moreover, two thirds of them were employed without a formal labor contract.

To conclude this section it is important to point out that Table 1 provides evidence that a significant part of beneficiaries of UI show signs of behavior that violate the program's objectives. However, this provides no information on the impact of UI on the transitions in the labor market. Information is not provided on how different the situation of these workers would be in the absence of this program or on the situation for those workers that were not receiving any benefits at the time of the survey.

\section{Methodology.}

The methodology adopted here is based on the work of Clark and Summers (1990). The population of working age (15 to 60 years) was divided into four possible occupational states: (a) employed and insured; (b) employed and non-insured; (c) inactive; and (d) unemployed.

The group of employed and insured workers includes all those employed in the private sector that held a formal labor contract and

\footnotetext{
${ }^{15}$ Those who did not have a job in the week of the survey but had some initiative to look for a job in the last month were considexed as unemployed. Those who did not have a job and did not actively look for work in the last month were considered as inactive.
} 
those employed in the public sector that joined the employment system of the private sector. The group of employed and non-insured includes those employed in the private sector without a formal labor contract; the self-employed; employers; and employees in the public sector, who, in adherence to the legislation that governs civil servants, did not have the right to UI benefits.

Employees without a formal labor contract and the self-employed are often grouped as workers in the informal sector. Since employees without a formal contract and the self-employed make up the vast majority of the employed and non-insured ( $86 \%$ in our sample), we refer to the latter group as informal employment. The group of employed and insured workers is referred to as formal employment.

Workers that did not have a job in the week of the survey but had some initiative to look for a job in the last month were considered as unemployed. Those that did not have a job and did not actively look for a job in the last month were considered as inactive.

\subsection{Theoretical Approach.}

Let " $p$ " be an individual in population " $P$ ". This individual may at any specific point in time be in one of the four occupational states in the labor market considered: formal employment $(f)$, informal employment $(i)$, unemployment $(u)$ and inactivity $(n)$.

Thus, for a specific period of time, we may define:

$\pi_{u}^{p}=$ fraction of time that individual " $p$ " spends in unemployment state.

$\pi_{n}^{P}=$ fraction of time that individual " $p$ " spends in inactivity state.

$\pi_{f}^{p}=$ fraction of time that individual " $p$ " spends in formal employment state.

$\pi_{i}^{p}=$ fraction of time that individual " $p$ " spends in informal employment state. 
For an individual selected at random from $P$ we would have:

$$
\Pi_{j}=\frac{1}{P} \sum_{p=1}^{P} \pi_{j}^{p} \quad \text { where, } j=\text { " } u \text { ", " } n \text { ", " } f \text { " and " } i \text { " }
$$

Thus, we may define the following aggregates:

$\frac{\Pi_{f}}{\Pi_{f}+\Pi_{i}}=$ rate of formal employment

$\frac{\Pi_{i}}{\Pi_{f}+\Pi_{i}}=$ rate of informal employment

$\frac{\Pi_{u}}{\Pi_{u}+\Pi_{f}+\Pi_{i}}=$ rate of unemployment

$\Pi_{n}=$ rate of inactivity

The main objective of this paper is to evaluate the evolution of these rates and the average duration in each of these occupational states and to identify how they were influenced by changes in the UI legislation.

Therefore let us assume that:

$$
\pi_{j}^{p}=\pi_{j}^{p}(c, b, a)
$$

where,

$\mathrm{a}=$ the time period representing the conditions in the labor market (time dummies)

$\mathrm{b}=$ the UI benefits

$\mathrm{c}=$ the vector of individual characteristics (gender, age, level of education and family position)

The strategy would be to model $\pi_{j}^{p}$, for each $p \in P$, in each time period (between 1984 and 1997), and thus calculate, for each period, the aggregate rates defined above. In order to observe the impact of 
UI, the procedure would be to recalculate these rates for $b=0$, and compare the two estimated trajectories.

The problem with this strategy is that $\pi_{j}^{p}(p=1,2, \ldots, P)$ are not observable variables. However, assuming that the probabilities of transitions among the various states are independent of the time that the individual remains in a particular state ${ }^{16}$, and making use of the steady state condition, we can show that:

$$
p_{r}^{p)} \pi^{p}=\pi^{p}
$$

where,

$$
p_{r}^{p}=\left[\begin{array}{cccc}
p_{f f}^{p} & p_{f i}^{p} & p_{f u}^{p} & p_{f n}^{p} \\
p_{i f}^{p} & p_{i i}^{p} & p_{i u}^{p} & p_{i n}^{p} \\
p_{u f}^{p} & p_{u i}^{p} & p_{u u}^{p} & p_{u n}^{p} \\
p_{n f}^{p} & p_{n i}^{p} & p_{n u}^{p} & p_{n n}^{p}
\end{array}\right] \text { and } \pi^{p}=\left[\begin{array}{c}
\pi_{f}^{p} \\
\pi_{i}^{p} \\
\pi_{u}^{p} \\
\pi_{n}^{p}
\end{array}\right]
$$

The matrix $p_{r}^{p}$ captures the transitions of individual $p$, and $p_{j k}^{p}$ is the probability of this individual being in state $k$ in $t+1$, provided he is in state $j$ in period $t$.

It is important to note that an equation of the linear system described in (3) is a linear combination of the other equations; in

\footnotetext{
${ }^{16}$ Transitions between occupational states in the labor market are treated as a Markov process. This hypothesis can be considered very strong [see Menezes-Filho and Picchetti (2000)] and, if such hypothesis is not valid, both the $\pi_{j}^{p}$ and the $\Pi_{j}$ would be biased. In relation to this criticism we would have three considerations to make: a) any heterogeneity among individuals in their transition probabilities will lead to apparent state dependence, so estimates that the transition probability changes with the time in the state can reflect differences in individual characteristics that are absent in the estimates; b) it is possible to evaluate the bias of our estimated aggregated rates by comparing them with the rates observed in the economy. We will see that our model fits very well the data; $c$ ) we are not properly interested in the aggregated rates, but in their variations due to the presence of UI and such variations should be less influenced by the hypothesis of no state dependence.
} 
other words, the matrix $p_{\tau}^{p}$ is not full rank. However, we may use the relation stated in $\pi_{f}^{p}+\pi_{i}^{p}+\pi_{u}^{p}+\pi_{n}^{p}=1$, substitute it in any of the equations, and through this process solve the system.

In addition to the expected period of time, the matrix $p_{r}^{p}$ makes it possible to calculate, for each $p \in P$, the expected duration of a spell in each of the occupational states, as follows.

Let $D_{j}^{p}$ be the expected duration of a spell in state $j$, thus:

$$
D_{j}^{p}=\frac{1}{1-p_{j j}^{p}}
$$

Thus, the procedure adopted in the study was to estimate the matrix $p_{\tau}^{p}(c, b, a)$ for each individual in the sample, and calculate the rates and aggregate durations of unemployment, inactivity, formal employment and informal employment for each of the years considered in the period. To evaluate the impact of UI, these aggregates were recalculated, considering the non-existence of UI, in other words, $b=0$.

\subsection{Estimation.}

3.2.1. The source of data. The basic source of information used in this study is the Monthly Employment Survey (Pesquisa Mensal de Emprego - PME) conducted by the Brazilian Geography and Statistics Institute (IBGE). The PME is a household survey conducted monthly for the six principal metropolitan regions of Brazil (SÃo Paulo, Rio de Janeiro, Porto Alegre, Belo Horizonte, Recife and Salvador). This study considered only individuals between 15 and 60 years of age that live in the So Paulo metropolitan region.

According to the data collection methodology of the PME, a household that enters the sample is surveyed for four consecutive 
Unemployment insurance and transitions in the labor market

months. After a period of eight months the household is once again surveyed for another four months. This feature of the survey allows us to observe the monthly transition between occupational states for the various individuals of the sample ${ }^{17}$. Each month, the PME sample includes four distinct groups: one entering the sample for the first time that year, one entering for the second time, one for the third, and finally one for the fourth time.

The procedure adopted was to treat each month as an independent sample, only utilizing the occupational information for the following month for individuals that made up the sample in a specific month. Each month only 1/4 of the sample was used and this was done in such a way that no individual would be included in the sample in two consecutive months ${ }^{18}$. This procedure generated a sample of 594,863 observations for the period between January 1984 and December 1997.

3.2.2. Estimating individual transition matrices. To estimate the individual probabilities of transition, four logit multinomial models were used, one for each occupational group in the base month. The dependent variable, assuming values from 1 to 4 , refers to the occupational state in the following month. The independent variables selected were: age, the square of age, the number of years of education completed, a dummy variable for gender, a dummy for heads of family, 13 dummies for the years, and a value for the UI

\footnotetext{
${ }^{17}$ Unfortunately, the PME does not inquire as to whether or not the unemployed worker receives unemployment benefits.

${ }^{18}$ We worked only with lots 1 and 2 of the PME. In January, lot 1 was used and the occupational situation of these individuals was observed in February. In February, lot 2 was used and the occupational situation of these individuals was observed in March. Lot 1 was once again used in March, and so on. Although the sample for each month was treated as an independent sample, it is possible for the same group of individuals to enter the sample again, but not in consecutive months.
} 
benefit, which was imputed for each individual in the sample.

For example, taking the individuals that were unemployed in the base month, the logit multinomial generates an estimate of the probability of a certain individual moving into each of the possible states in period $t+1$, provided that the individual was unemployed in period $t$. The estimated coefficients were used to plot the probabilities for each of the individuals in the sample. Thus, the estimates of the models provide an estimate of $p_{\tau}^{p}$, for each $p \in P$.

3.2.3. Estimating UI benefits. The last step necessary for implementing our estimates is to impute a benefit for each individual in the sample. Note that UI provides the right to receive benefits for those that "buy" an insurance (obtain a job in the formal sector) and are fired by the firm. Essentially the aim is to evaluate how this right affects the transitions in the labor market ${ }^{19}$. Thus we must impute the expected benefit for an individual employed in the formal sector when he is fired. Therefore, in order to evaluate the benefits granted by the UI program, it is necessary to observe three distinct elements that occur in the payment of the UI benefit: the replacement rate, the duration of the benefits, and the ease of eligibility. Since the payment of UI in Brazil began in July 1986, a null value was attributed to the benefit of individuals in samples between January 1984 and June 1986. For all other situations, the procedure adopted is as follows.

\footnotetext{
${ }^{19}$ Clark and Summers (1990) sought to evaluate the effect of these rights for each individual in the sample, based on the worker's occupational state at the time of the survey. One of the problems with this procedure was that the worker's occupationalstate could already be a reflection of the program. This led to a problem with endogeneity. However, it is almost impossible for a study of this type to be completely free of problems with endogeneity. At any rate, the procedures adopted by the authors are not appropriate for the present study since the necessary information is not available. The PME does not inquire as to whether or not the unemployed worker receives unemployment benefits.
} 
We took the view that the important factor is the total volume of benefits that the worker has the right to receive, in other words, the replacement rate multiplied by the number of installments ${ }^{20}$. For the calculation of the replacement rate, a formal sector wage was imputed for each individual in the sample. The table of benefits in effect at the time was then applied to this imputed wage. The imputing procedure was based on a regression of the log-wage for each year, only for workers in the formal sector, using the following independent variables: age, the square of age, the number of years of education completed, a dummy variable for gender, and $n-1$ dummies for months, where $n$ is the number of months in the year that has individuals in the sample ${ }^{21}$. Thus, the replacement rate imputed varies among individuals of different characteristics in any one year, and over time in a single group.

The number of benefit installment payments was considered to be 4 for the entire period. This was the maximum number of installments allowed until June 1994. After this date, the number of benefit payments varied from 3 to 5 , depending on the worker's period of employment. Since we do not have more precise information to calculate the expected number of installments, employees in the formal sector that are fired are arbitrarily given the intermediate number of installments.

The replacement rate and the number of installments provide

${ }^{20}$ It can be argued that the right to receive $\mathrm{R} \$ 500,00$ in 5 monthly installment payments of $\mathrm{R} \$ 100,00$ has a very different impact than the right to receive $\mathrm{R} \$ 500,00$ in 2 installments of $\mathrm{R} \$$ 250,00 . In practice, however, since the maximum number of installment payments has varied little in Brazil, this hypothesis does not a strong impact.

${ }^{21}$ Except for the years 1984 and $1985, n=12$. In 1984, the regression was estimated only for the second half of the year $(n=6)$ and in 1985 there were no individuals in December $(n=11)$. This was due to a change in the survey questions, which made it impossible to locate these individuals in January 1986. The expected wages were used in the place of observed wages, even for individuals in the formal sector. 
us with the total amount of benefits that a worker in the formal sector has the right to receive in the event that he or she is fired, conditional on the worker to be eligible. However, for this study it is important to obtain the expected benefit amount not conditional on the worker to be considered eligible. Thus, we must multiply the value obtained above by the probability of the worker meeting the necessary eligibility criteria when he or she is fired. This probability is strongly determined by legislation, which, as we have seen, has changed significantly. The problem lies in estimating this probability as a function of legislation.

Note that that if we define $\alpha_{i}$ as the probability that an individual " $i$ " is fired from his job in a certain period (if he is employed in the formal sector), and assuming that the only criteria for eligibility for UI is to remain in a job for a period of time in excess of $n$, then the probability that this individual would have access to benefits, in case he or she was fired, will be $\left(1-\alpha_{i}\right)^{n}$. If the probability of dismissal from a job was fixed, we would be able to use information about the number of beneficiaries and the number of workers in the formal sector that were fired to evaluate the impact of legislation on the probability of eligibility. For a group of individuals of a specific characteristic, the probability of eligibility could be calculated simply by the ratio between the number of beneficiaries and the number of workers fired. Changes in this ratio between different periods would be fully explained by changes in the legislation, that is, changes in $n$.

The problem with this procedure is that the probabilities of dismissal are not fixed. Probabilities may vary due to general conditions in the economy - captured, at least in part, by time dummies - and changes in the behavior of workers, influenced by changes in legislation. Thus, this procedure incurs in problems of endogeneity. However, these problems could not be eliminated. The information 
on beneficiaries and dismissals by segment of the population could not be obtained either. We were only able to obtain information for the complete set of workers. Thus, the procedure adopted was as follows:

Based on the legislation in effect, four periods in which the eligibility characteristics remained relatively stable were identified:

i) July 1986 to January 1990

ii) February 1990 to December 1991

iii) January 1992 to June 1994

iv) July 1994 to December 1997

Using information from the Labor and Employment Ministry, the ratio of beneficiaries to fired workers was calculated for each of the years ${ }^{22}$. The average of the ratios for the years 1987, 1988 and 1989 was used as the probability that a worker fired in the formal sector would have access to UI benefits for the first period (17.37\%). For the second period, the average between 1990 and 1991 was used (47.21\%). The average of the years 1992 and 1993 was used as the probability of eligibility for the third period (66.16\%). Finally, for the fourth period the average of the years 1995, 1996 and 1997 was used $(64.95 \%)$. The hypothesis is that the changes, between the periods, in that ratio are explained fundamentally by changes in the legislation. An alternative to this procedure would be to use dummies of periods interacting with the value of the UI benefits.

Thus, for each individual the benefit was considered to be the product of the replacement rate, the maximum number of installments and the probability of eligibility, in accordance with the hypothesis described above.

${ }^{22}$ This information was used for the country as a whole. 


\section{Results.}

On the basis of the procedures described above we sought to identify the impact of UI on the rate and spell duration of employment in the formal sector, unemployment and inactivity. In the multinomial logit regressions, the coefficient of the benefit variable was not statistically significant (at $5 \%$ ) in 5 of the 12 possible cases, indicating that not all transitions are affected by UI benefits. This occurred in the occupational transitions from formal employment to unemployment; from formal employment to inactivity; from informal employment to unemployment; from unemployment to formal employment; and from unemployment to informal employment ${ }^{23}$. However, the values of the coefficients were considered for the purposes of the simulation, that is, the significance level was not taken into account.

\subsection{Rate of formal employment.}

Figure 1 shows the evolution of the rate of formal employment for the Metropolitan São Paulo region. The observed rate was obtained directly from the sample and as such its comparison with the estimated rate provides a measure of the fitness of the estimation procedure. The result shows that the estimated model does a relatively good job in predicting the trajectory of this rate. Comparison between the estimated and simulated rates (estimated with $b=0$ ) evaluates how UI affected its behavior. The figure points to a sharp reduction in formal employment beginning in 1989, but shows that UI has little influence on its trajectory.

The tables in the appendix show the annual averages for the estimates of the probabilities of transitions, both with and without the

\footnotetext{
${ }^{23}$ Remaining in the same occupational state was considered as reference in each regression. Results of regressions are available upon request.
} 
impact of benefits. The tables show that the probability of moving out of the formal labor market $\left(1-P_{f f}\right)$ is only slightly affected by $\mathrm{UI}^{24}$. The transition from formal to informal employment experienced a slight increase with the inclusion of benefits, while the probabilities of the transition from formal employment to unemployment and inactivity experienced a slight reduction. It is important to remember that in the latter two cases, the benefit coefficients were not statistically significant. In this light, our results do not support the hypothesis that UI provides incentives for workers to adopt behavior that would lead to be fired from their job in the formal sector. On this point our study presents results that reinforce the studies conducted by developed countries, which do not present results of a strong impact of UI on the flow out of the employment state [Atkinson and Micklewright (1991)].

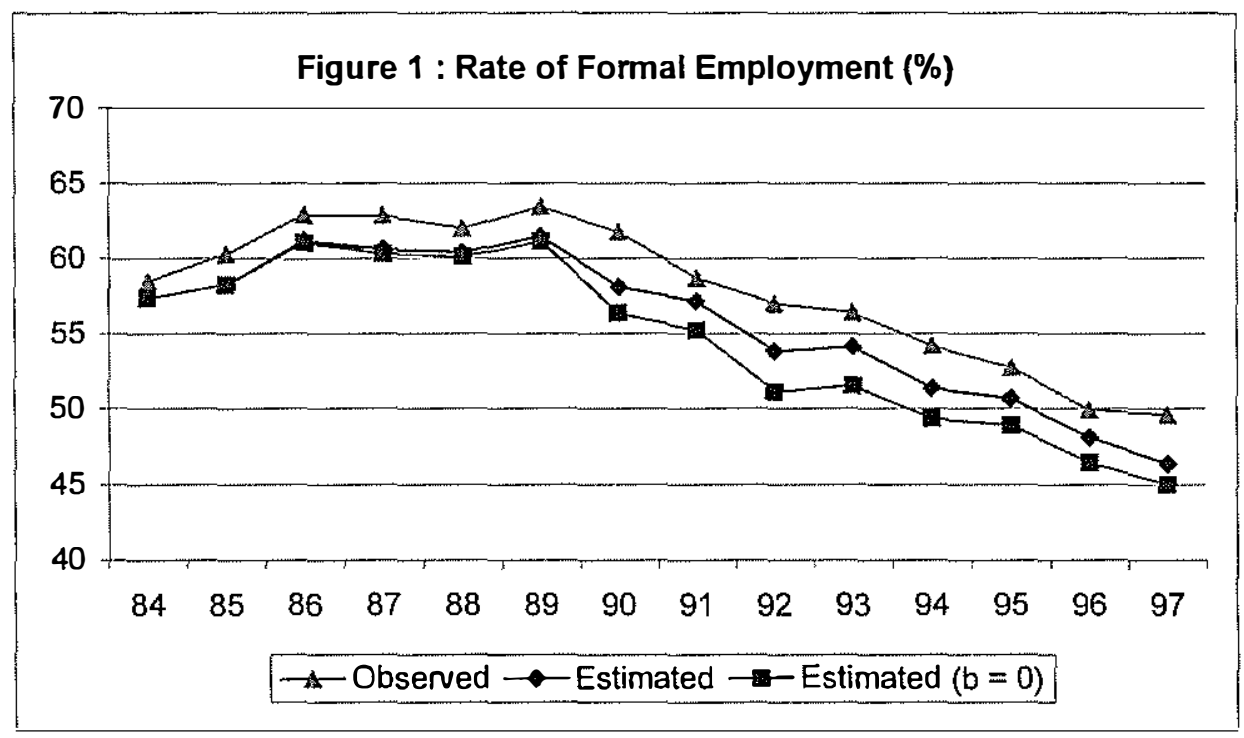

${ }^{24}$ This means that spell duration in the formal sector is only slightly affected by UI. 
José Paulo Zeetano Chahad and Reynaldo Fernandes

Figure 2 : Duration of Informal Employment

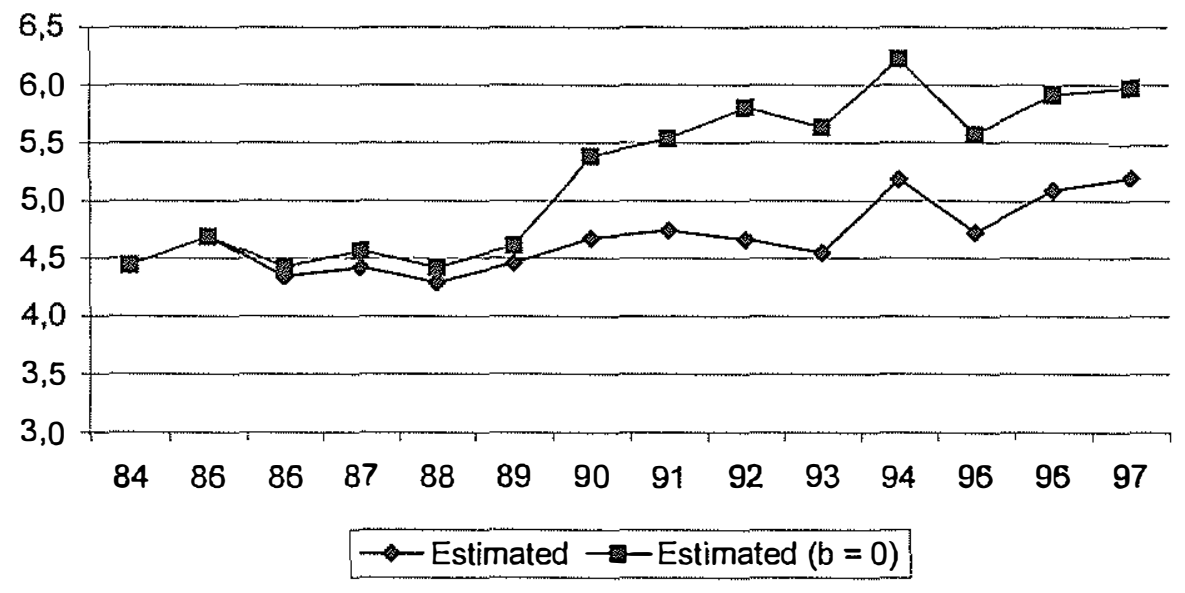

On the other hand, UI has a positive impact on the transition from informal employment to formal employment. The probability of a transition out of the informal sector rises with the inclusion of UI, which reduces the average duration of a complete employment period in this occupational state (see Figure 2). The transition from unemployment to the informal sector remains practically unchanged with the introduction of UI, while the transition from inactivity is slightly reduced.

\subsection{Rate of unemployment.}

Figures 3 and 4 show a surprising result: UI has a negative effect both on the rate and average duration of unemployment. This contradicts all the evidence available for developed countries. Using the year 1997 as a base, the rate of unemployment fell from 8.5\% to $7.04 \%$ with the inclusion of benefits, while the duration of unemployment was reduced in 0.13 months. Figure 3 also shows that the estimation procedures adopted forecast with reasonable precision the trajectory of the rate of unemployment. 
Unemployment insurance and transitions in the labor market
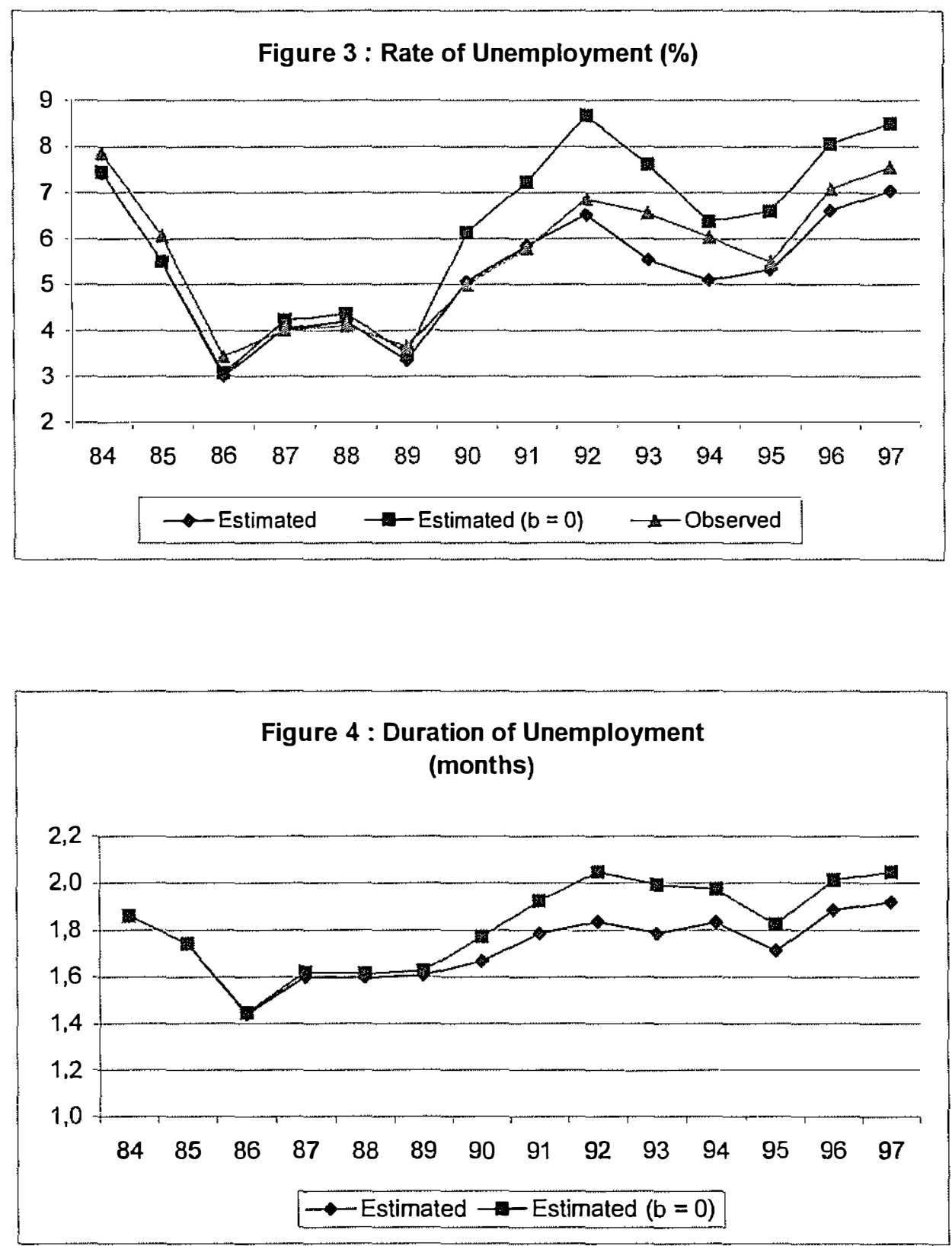
The relationship between unemployment and inactivity merits special attention. The average duration of a complete period in unemployment is two months, which is very low. The PME contains a question for the unemployed that asks for how long they have been in this situation. According to the survey, the average period of unemployment is around four months, that is, two times the value of our estimate.

The hypothesis that the probabilities of transitions follow a Markov process implies that the average duration of a period of unemployment can be calculated by two methods. First, by the average of the inverse of the individual probabilities of moving out of unemployment, and also by the average period of unemployment of those workers that at any given moment are unemployed. Thus, a portion of the difference observed could be due to our hypothesis that the probability of moving out of the state of unemployment is independent of the period of time that the person is in this situation. This, however, does not seem to fully explain the story. Another important aspect is the way in which the question about the period of unemployment is asked. For example, a worker who lost his job eight months ago and has not found a job since can declare that he has been unemployed for eight months. However, this does not mean that he actively searched for a job in all of the eight months. According to our definitions, he must have alternated between a situation of unemployment and inactivity during these eight months.

The impact that was to be expected on the state of unemployment seems to be occurring on the state of inactivity. The probabilities of transitions (see the tables in the appendix) show that the increase in the flow out of unemployment as a result of UI basically moves into inactivity. The transition from unemployment to formal employment rose slightly with the introduction of UI, while the probability of the transition to informal employment remains unchanged. 
Unemployment insurance and transitions in the labor market

On the other hand, the probability of moving out of inactivity into employment or into unemployment was significantly reduced.

\subsection{Rate of inactivity.}

The principal impact of UI is an increase in both the rate and average duration of inactivity, as shown in figures 5 and 6 . Figures for 1997 show that UI increases the rate of inactivity from $25.93 \%$ to $32.75 \%$, and lengthens the average period of inactivity from 4.2 months to 5.3 months. Once again, our estimates forecast the trajectory of inactivity with a high degree of precision.

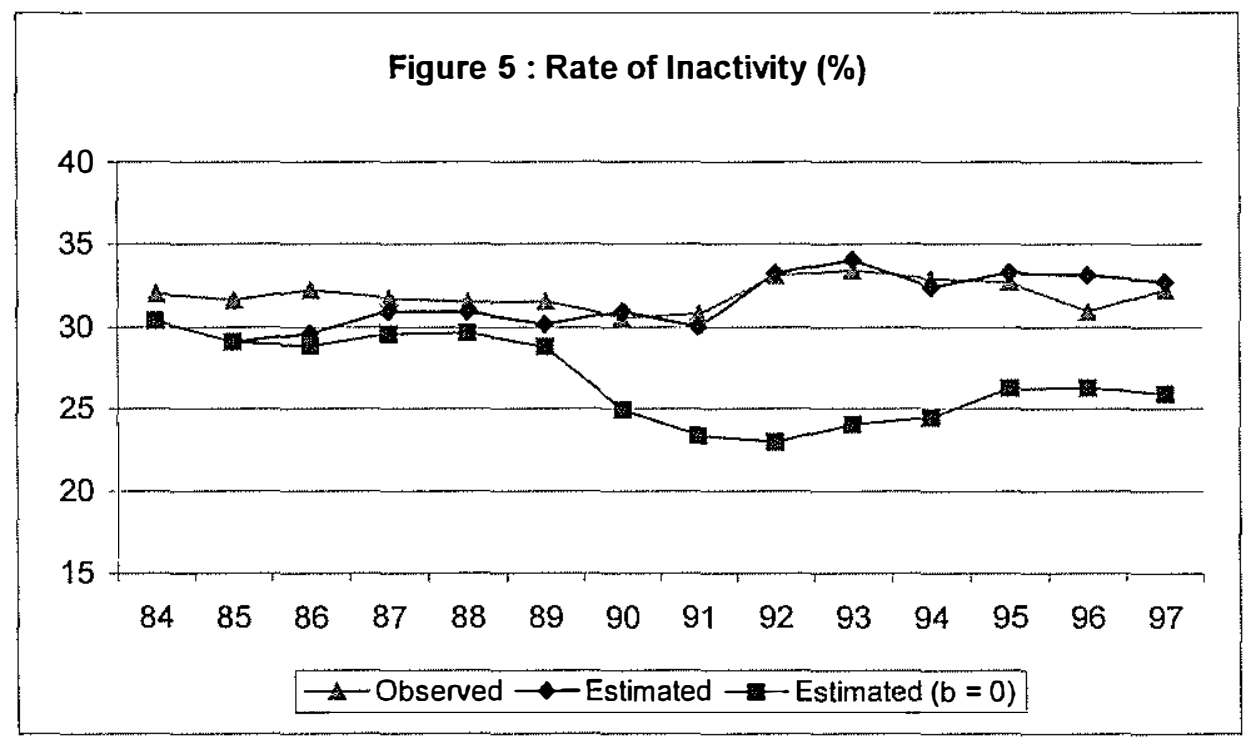


José Paulo Zeetano Chahad and Reynaldo Fernandes

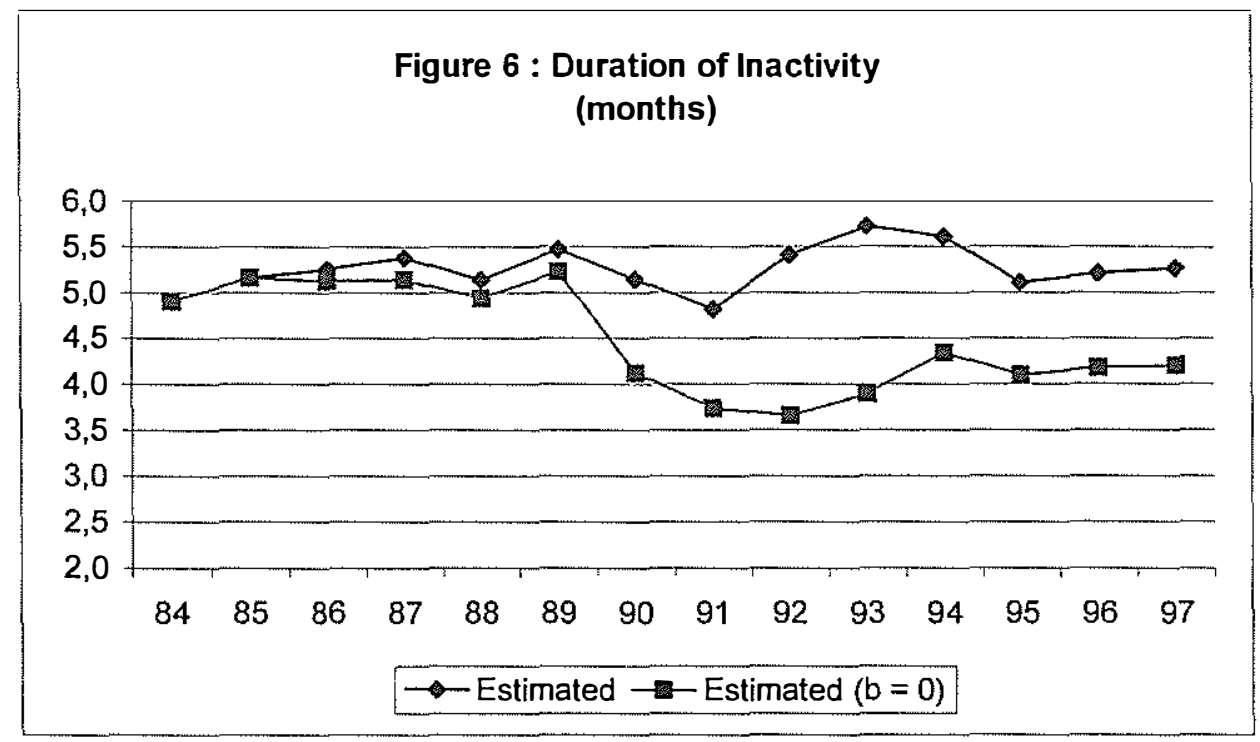

The probabilities of transitions show that, as a result of UI, the flow out of inactivity is reduced in relation to all other states. On the other hand, the probability of transition from unemployment and informal employment to inactivity rises. It is worth emphasizing that our sample contains only people with less than 61 years of age, which should reduce the weight of retirement on the rate of inactivity. Therefore, the evidence suggests that, on average, individuals reduce their work effort with the advent of UI.

In short, the impact of an increase in the rate and duration of inactivity due to the existence of UI is without a doubt the most important result obtained in this study, but it deserves a more detailed investigation. An initial interpretation is that individuals that have lost their jobs may be reducing the amount of effort used in the search for employment. Workers leave the labor market only to return when the period of benefit payment is nearly over. This is a 
Unemployment insurance and transitions in the labor market

negative effect of UI. Another interpretation is that our estimation is reflecting the "added worker effect". Our model was specified with individual benefits, but there can exist a strong correlation between the benefits of heads and non-heads and the results can reflect the impact of the head benefit on non-head inactivity ${ }^{25}$.

According to the arguments presented above, an interesting issue to analyze would be to verify the UI impact for two distinct subpopulations: heads of families and non-heads. Besides the "added worker effect", UI may have a different direct impact on these subpopulations. In general, non-heads of families have a smaller attachment to the workforce and a higher replacement rate, since their wages are, on average, lower. This analysis is carried out in the subsequent subsection.

\subsection{The impact of UI on heads and non-heads.}

The estimation procedures presented above were reproduced for the subpopulations of heads and non-heads of families ${ }^{26}$. So, new multinomial logits were estimated and the main results for heads of families are shown in figures 7,8 and 9. The figures show that the qualitative result of UI on the rates of formal employment, unemployment and inactivity on heads of families was similar to that for the total population. However, the intensity of this effect was greatly reduced, especially on the rate of inactivity. Our results, considering only heads of families, indicate that UI has a very weak impact.

\footnotetext{
${ }^{25}$ Cullen and Gruber (2000) found that, for the U.S. case, wives of unemployed husbands would work $30 \%$ more hours if there were no UI income.

${ }^{26}$ In this subsection and in the next one we will concentrate the analysis on the frequency of each one of the states, and not on their duration. However, the conclusions for duration are similar.
} 
José Paulo Zeetano Chahad and Reynaldo Fernandes
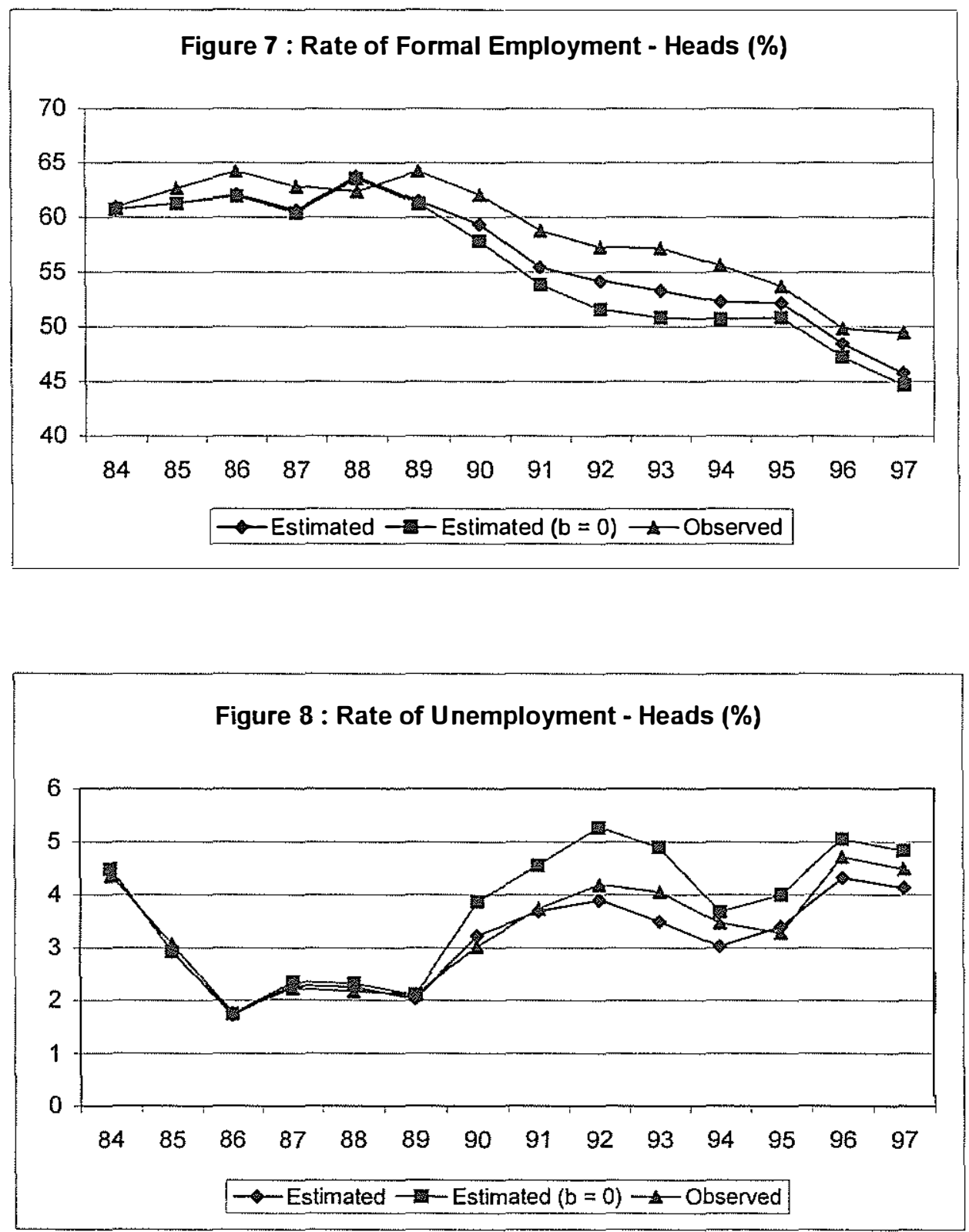
Unemployment insurance and transitions in the labor market

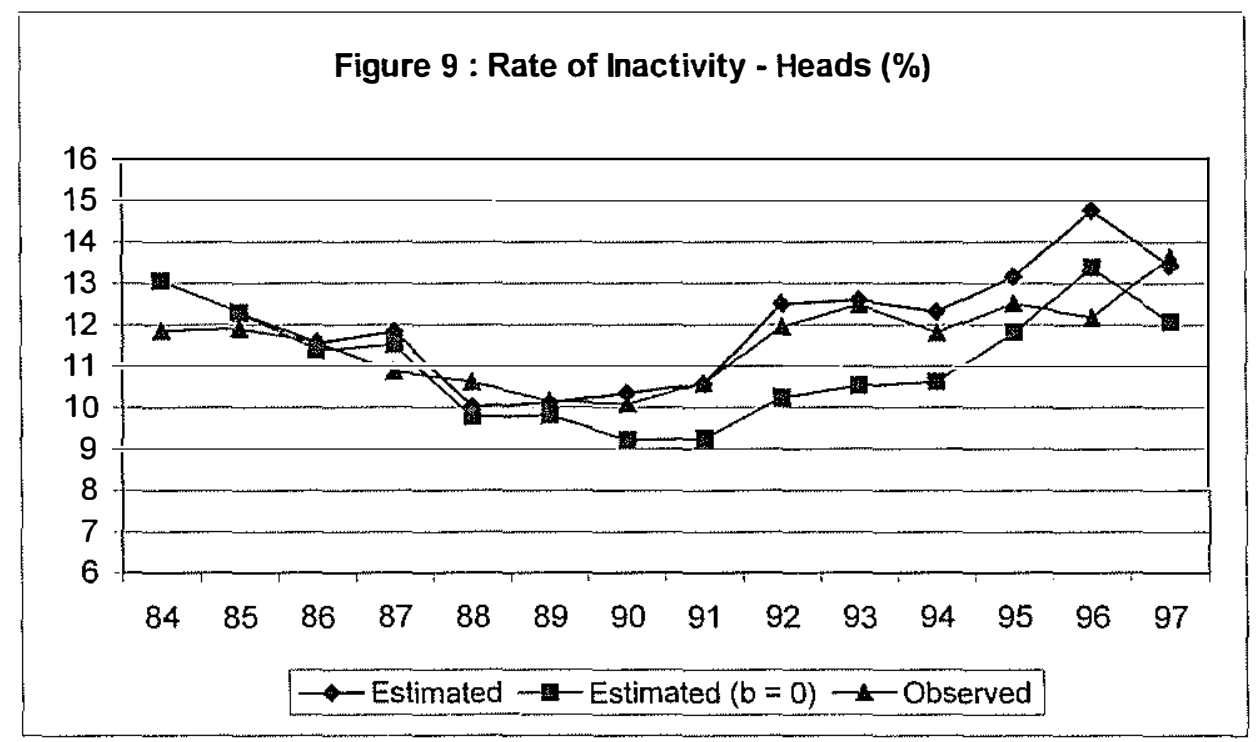

The above results suggest that the impact of UI basically acts on the population of non-heads of families, which can also be seen in figures 10, 11 and 12. The impact of UI on the rate of formal employment was practically nonexistent. This result is not very different from the result obtained for the population as a whole. The qualitative results for the rates of unemployment and inactivity are more or less the same, but are much more intense, especially for the rate of inactivity. Using 1997 as a base, our simulations indicate that UI increases the rate of inactivity for non-heads of families by 11 percentage points. 
José Paulo Zeetano Chahad and Reynaldo Fernandes

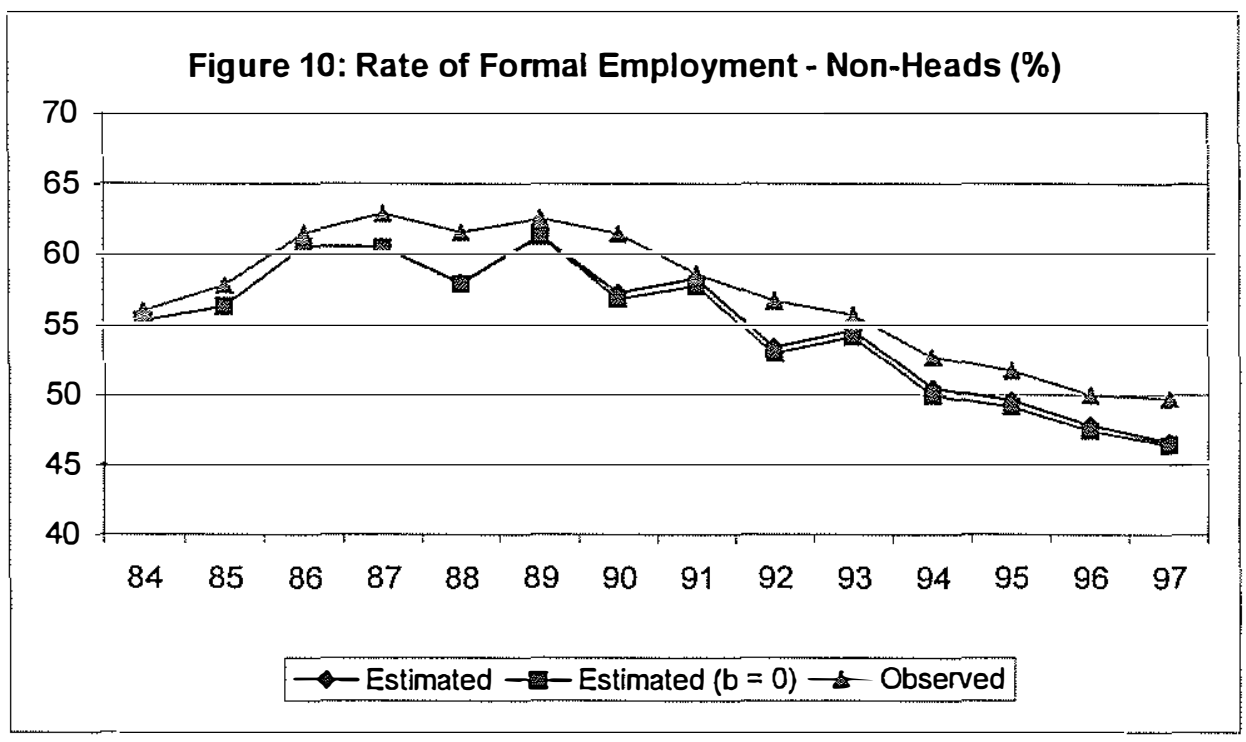

Figure 11: Rate of Unemployment - Non-Heads (\%)

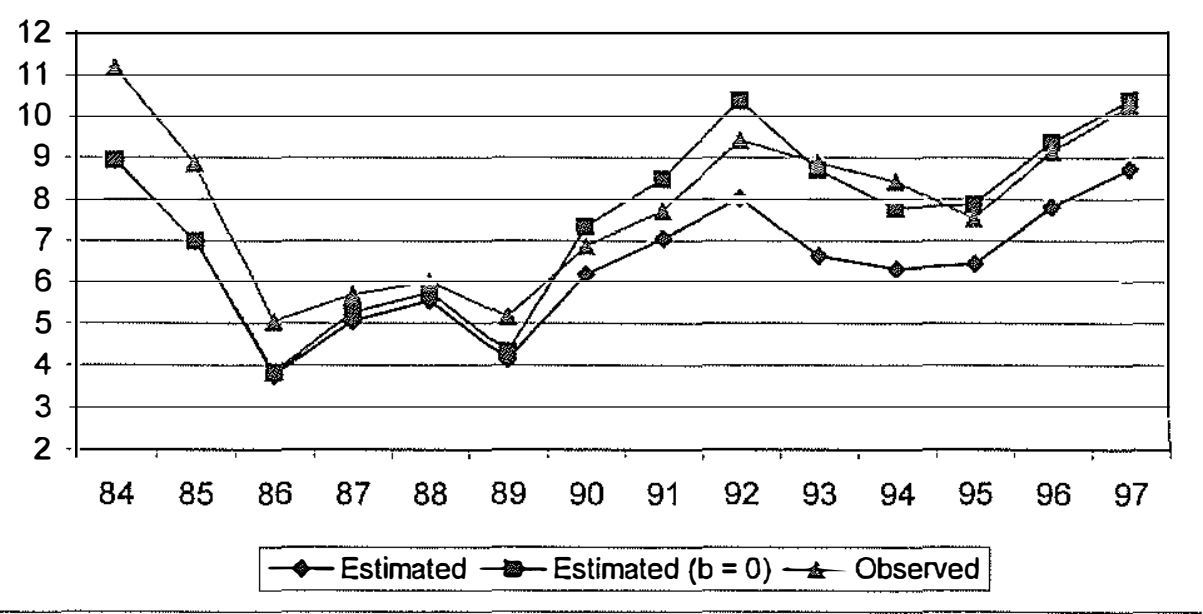


Unemployment insurance and transitions in the labor market

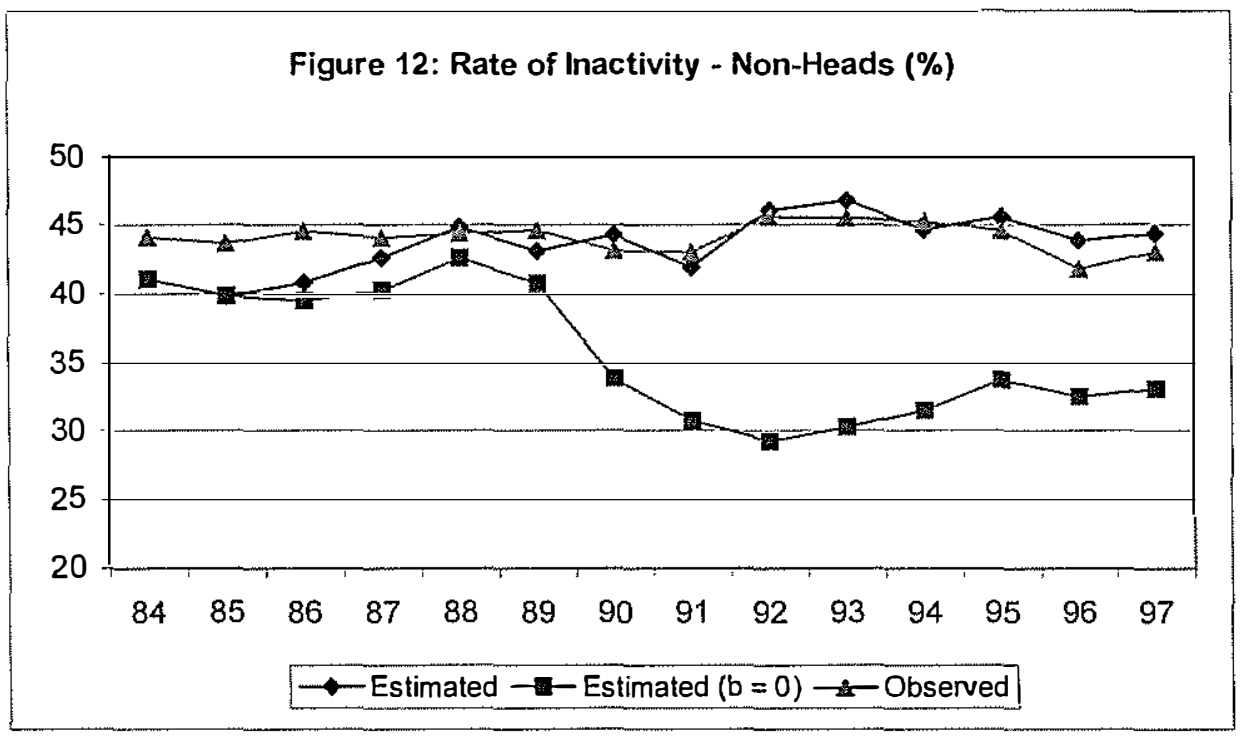

As mentioned before, this result could be due to the fact that the same benefit has a stronger effect on non-heads of families, that the level of benefits of non-heads of families are proportionally higher and/or it could be due to the "added worker effect". To evaluate this aspect we include the heads' benefits in the non-heads' regressions and the heads' characteristics (gender, age, education) to identify the impact of UI legislation. Figure 13 shows the results of the latter procedure for rate of inactivity. When we turn off both the individual benefit $(b=0)$ and the head's benefit $(b$.head $=0)$ the result is very similar to the one in figure 12 , but when only the head's benefit was switched off the impact was practically nonexistent. This is evidence against the "added worker effect" and it suggests that the UI impact on non-head's inactivity occurs only via the non-head's benefit itself. 


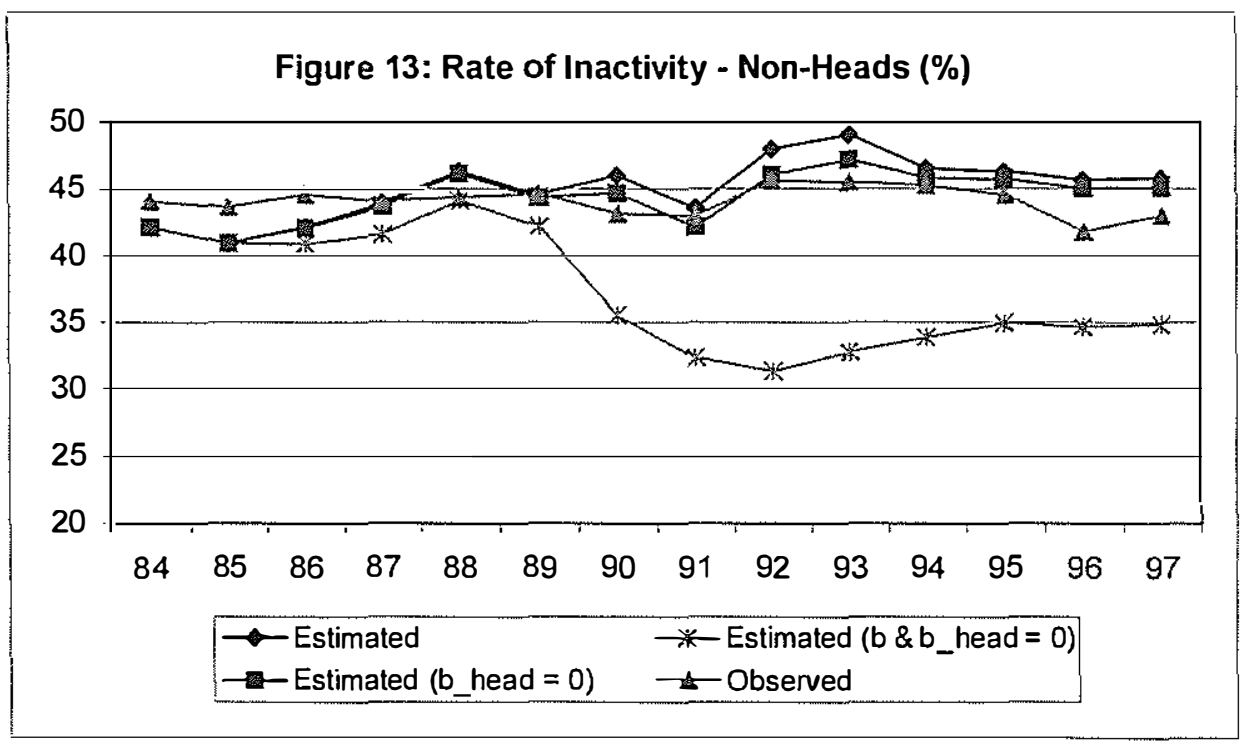

\section{Final considerations.}

This paper investigated the impact of unemployment insurance (UI) on the transitions in the Brazilian labor market. Our results do not support the hypothesis that UI provides incentives for workers to take actions that lead to their dismissal from their job in the formal sector. The impact of the replacement of the unemployed worker's income on the rate of formal employment was insignificant. A surprising result was that UI has a negative effect both on the rate and average duration of unemployment. This, however, does not occur because workers are able to find a job in less time, but because they join the ranks of the inactive workers.

The positive effect of UI on inactivity is without a doubt the most important result of this investigation. However, this result occurs basically among non-heads, rather than among the heads of 
families. An explanation for this result is that non-heads may reduce their efforts in the active search for employment, which increases their probability of being classified as inactive. This could happen because non-heads of families have, on average, lower wages and, therefore, are less important for the family income and have a higher replacement rate. Our evidence does not support the hypothesis that the rise in non-head's inactivity occurs due to head's benefits, the "added worker effect" hypothesis.

Submitted in April 2002. Revised in September 2002.

\section{References}

Acemoglu, D. \& R. Shimer 1999a. "Efficient Unemployment Insurance". Journal of Political Economy, 107(October)893-928.

Acemoglu, D. \& R. Shimer 1999b. "Productivity Gains from Unemployment Insurance". National Bureau of Economic Research Working Paper 7352.

Atkinson, A. B. \& J. Micklewright 1991. "Unemployment Compensation and Labor Transition: A Critical Review". Journal of Economic Literature, 59 (December)1679-1727.

Barros, R., C. H. Corseuil \& M. Fogel 1999. "Os Incentivos Adversos e a Focalização dos Programas de Proteção ao Trabalhador no Brasil". Seminário: O Sistema Brasileiro de Proteção Social ao Desempregado, Ministério do Trabalho e Emprego, São Paulo.

Chiu, H. W. \& E. Karni 1998. "Endogenous Adverse Selection and Unemployment Insurance". Journal of Political Economy, 106(August)806-827.

Clark, K. B. \& L. H. Summers 1990. "Unemployment Insurance and Labor Market Transitions". In: Summers L. H. Understanding Unemployment. The MIT Press, Cambridge, Massachusetts. 
Cullen, J. B. \& J. Gruber 2000. "Does Unemployment Insurance Crowd out Spousal Labor Supply?" Journal of Labor Economics, 18(July)546-572.

Fields, G. S. 1990. "Labour Market Modelling and the Urban Informal Sector: Theory and Evidence". In: Turnham, D., Salomé, B. and Schwarz, A. (eds). The Informal Sector Revisited. OECD, Paris.

Layard, R., S. Nickell \& R. Jackman 1991. Unemployment: Macroeconomic Performace and the Labour Market UK: Oxford University Press.

Marimon, R. \& F. Zilibotti 1999. "Unemployment versus Mismatch of Talent: Reconsidering Unemployment Benefits". Economic Journal, 109(April)266-291.

Menezes-Filho, N. \& P. Picchetti 2000. "Os Determinantes da Duração do Desemprego em São Paulo". Pesquisa e Planejamento Econômico, 30(Abril)23-48.

Meyer, B. D. 1990. "Unemployment Insurance and Unemployment Spells". Econometrica, 58(July)757-782.

Meyer, B. D. 1995. "Lessons from the U. S. Unemployment Insurance Experiments". Journal of Economic Literature, 33(March)93-131.

Schimid, G. \& B. Reissert 1995. "Unemployment Compensation and Labor Market Transitions". In: Schimid, G., O'Reilly, J. and Schömann, K. (eds). International Handbook of Labour Policy and Evaluation. Edward Elgar Publishing Company United Kingdom.

Thomas, M. R. 1999. "Unemployment Insurance in Brazil". Seminário: O Sistema Brasileiro de Proteção Social ao Desempregado, Ministério do Trabalho e Emprego, São Paulo. 
Unemployment insurance and transitions in the labor market

\section{Appendix}

Probabilities of transitions among occupational states (\%)

\begin{tabular}{lcccccccc}
\hline Year & $P_{u u}$ & $P_{u u}(b=0)$ & $P_{u n}$ & $P_{u n}(b=0)$ & $P_{u f}$ & $P_{u f f}(b=0)$ & $P_{u i}$ & $P_{u i}(b=0)$ \\
84 & 46.24 & 46.24 & 22.43 & 22.43 & 7.89 & 7.89 & 23.44 & 23.44 \\
87 & 37.51 & 38.27 & 25.87 & 25.42 & 16.31 & 15.91 & 20.31 & 20.39 \\
91 & 44.03 & 48.02 & 26.91 & 24.25 & 9.00 & 7.67 & 20.06 & 20.06 \\
93 & 44.02 & 49.78 & 29.38 & 25.20 & 6.73 & 5.27 & 19.86 & 19.76 \\
97 & 47.89 & 51.15 & 27.44 & 24.89 & 4.70 & 4.11 & 19.97 & 19.86 \\
\hline
\end{tabular}

\begin{tabular}{lcccccccc}
\hline Year & $P_{n u}$ & $P_{n u}(b=0)$ & $P_{n n}$ & $P_{n n}(b=0)$ & $P_{n f}$ & $P_{n f}(b=0)$ & $P_{n i}$ & $P_{n i}(b=0)$ \\
84 & 8.27 & 8.27 & 79.63 & 79.63 & 2.50 & 2.50 & 9.60 & 9.60 \\
87 & 5.00 & 5.43 & 81.41 & 80.55 & 4.68 & 4.79 & 8.92 & 9.24 \\
91 & 7.17 & 11.04 & 79.26 & 73.27 & 3.71 & 4.10 & 9.86 & 11.59 \\
93 & 5.40 & 10.47 & 82.53 & 74.33 & 3.25 & 3.85 & 8.81 & 11.36 \\
97 & 7.56 & 10.82 & 81.01 & 76.19 & 2.07 & 2.26 & 9.36 & 10.73 \\
\hline
\end{tabular}

\begin{tabular}{lcccccccc}
\hline Year & $P_{f u}$ & $P_{f u}(b=0)$ & $P_{f n}$ & $P_{f n}(b=0)$ & $P_{f f}$ & $P_{f f}(b=0)$ & $P_{f i}$ & $P_{f i}(b=0)$ \\
84 & 1.23 & 1.23 & 2.05 & 2.05 & 90.83 & 90.83 & 5.88 & 5.88 \\
87 & 1.19 & 1.21 & 2.63 & 2.67 & 89.46 & 89.54 & 6.72 & 6.58 \\
91 & 1.35 & 1.50 & 2.45 & 2.62 & 89.99 & 90.33 & 6.21 & 5.55 \\
93 & 1.08 & 1.26 & 2.76 & 3.05 & 88.34 & 89.05 & 7.82 & 6.65 \\
97 & 0.94 & 1.04 & 2.26 & 2.42 & 88.16 & 88.64 & 8.65 & 7.90 \\
\hline
\end{tabular}

\begin{tabular}{lcccccccc}
\hline Year & $P_{i u}$ & $P_{i u}(b=0)$ & $P_{i n}$ & $P_{i n}(b=0)$ & $P_{i f}$ & $P_{i f}(b=0)$ & $P_{i i}$ & $P_{i i}(b=0)$ \\
84 & 3.86 & 3.86 & 9.33 & 9.33 & 9.33 & 9.33 & 77.49 & 77.49 \\
87 & 1.80 & 1.88 & 9.41 & 8.79 & 11.41 & 11.22 & 77.38 & 78.10 \\
91 & 2.37 & 2.86 & 8.93 & 6.36 & 9.78 & 8.85 & 78.92 & 81.93 \\
93 & 2.40 & 3.13 & 9.04 & 5.54 & 10.55 & 9.08 & 78.02 & 82.24 \\
97 & 2.68 & 3.22 & 8.31 & 5.96 & 8.26 & 7.56 & 80.75 & 83.26 \\
\hline
\end{tabular}

